\title{
Cryptococcus neoformans mating and virulence are regulated by the G-protein $\alpha$ subunit GPA1 and CAMP
}

\author{
J. Andrew Alspaugh, ${ }^{1,4}$ John R. Perfect, ${ }^{3,4}$ and Joseph Heitman ${ }^{1,2,5,6}$ \\ Departments of ${ }^{1} \mathrm{Genetics},{ }^{2} \mathrm{Pharmacology},{ }^{3} \mathrm{M}$ icrobiology, and ${ }^{4} \mathrm{M}$ edicine, and the ${ }^{5} \mathrm{H}$ oward Hughes Medical Institute, Duke \\ University M edical Center, Durham, N orth Carolina 27710 USA
}

\begin{abstract}
This study explores signal transduction pathways that function during mating and infection in the opportunistic, human fungal pathogen C ryptococcus neoformans. The gene encoding a G-protein $\alpha$ subunit homolog, G PA 1, was disrupted by homologous recombination. The gpal mutant strain was viable but exhibited a defect in mating in response to nitrogen starvation. Additionally, the gpal mutant strain failed to induce two well-established virulence factors-melanin synthesis, in response to glucose starvation; and capsule production, in response to iron limitation. As a consequence, virulence of the gpal mutant strain was significantly attenuated in an animal model of cryptococcal meningitis. Reintroduction of the wildtype G PA 1 gene complemented the gpal mutant phenotypes and restored mating melanin and capsule production, and virulence Similarly, exogenous CAMP also suppressed the gpal mutant phenotypes, restoring mating and production of melanin and capsule. These obsenvations support a model in which GPA1 has a role in sensing diverse environmental signals required for mating and virulence by regulating cAMP metabolism in C. neoformans.
\end{abstract}

[Key Words: Cryptococcus; G protein; signal transduction; pathogenesis; capsule; melanin]

Received August 15, 1997; revised version accepted September 23, 1997.

All cells must be able to sense and respond to changes in the environment. In the specific case of pathogenic microorganisms, a dramatic change in external signals occurs as the organism enters the host. There, host-specific signals often induce the production of microbial virulence factors that allow the pathogen to survive within this new environment (Mekalanos 1992). Elements of these signaling and response pathways in microorganisms include cell-surface receptors, adapter proteins such as guanine nucleotide-binding proteins (G proteins) or protein kinases, and regulatory elements including second messengers and transcriptional regulators. Our studies focus on how signal transduction cascades regulate virulence in pathogenic fungi.

Cryptococcus neoformans is a heterothallic, basidiomycetous, pathogenic fungus that most often infects immunocompromised patients. The preval ence of disease caused by this organism has increased dramatically as a result of human immunodeficiency virus (HIV) infection, organ transplantation, cytotoxic chemotherapy, and corticosteroid use.

C. neoformans is one of the most common invasive, opportunistic pathogens in acquired immune deficiency syndrome (AIDS) patients and is the most common

${ }^{6}$ Corresponding author.

E-MAIL heitm001@mc.dukeedu; FAX(919)684-5458. cause of fungal meningitis worldwide (Mitchell and Perfect 1995). Established pathogenic traits of this organism include an antiphagocytic polysaccharide capsule (Granger et al. 1985; Kwon-Chung and Rhodes 1986; Chang et al. 1996), melanin elaborated within the cell wall as an antioxidant (Kwon-Chung et al. 1982; Wang et al. 1995; Sal as et al. 1996), the ability to grow at $37^{\circ} \mathrm{C}$ (Kwon-Chung and Rhodes 1986; Odom et al. 1997), prototrophy (Perfect et al. 1993), and $\alpha$-mating type (KwonChung et al. 1992).

Environmental signals that induce virulence factors in C. neoformans have been identified previously. For example, capsul eformation in C. neoformans is induced by severe iron deprivation (Vartivarian et al . 1993) or exposure to mammalian physiologic $\mathrm{CO}_{2} / \mathrm{HCO}_{3}{ }^{-}$levels (Granger et al. 1985). Melanin production requires the presence of diphenolic substrates and is induced by glucose deprivation (N urudeen and A hearn 1979; Polacheck et al. 1982; Torres-Guererro and Edman 1994; Williamson 1994). Similarly, mating and haploid fruiting, both of which may serve to produce small $(1-2 \mu)$, potentially infectious spores, are induced by nitrogen starvation (Kwon-Chung 1976; Wickes et al. 1996). Although some of the environmental signals that induce virulence factors have been identified, the specific signal transduction cascades that detect these signals and regulate expression of these and other virulence factors have only recently begun to be elucidated (Odom et al. 1997). 
Recently, several virulence-associated signaling cascades in plant fungal pathogens have been found to involve regulation by $\mathrm{G}$ proteins. For example, the $\mathrm{G} \alpha$ subunit homolog $\mathrm{G}$ pa3 is required for mating and virulence in the maize pathogen U stilago maydis (Regenfelder et al. 1996). Similarly, the $\mathrm{G} \alpha$ subunit CPG-1 regulates mating and virulence in Cryphonectria parasitica, the cause of chestnut blight (Gao and Nuss 1996). A gene encoding a cryptococcal G-protein $\alpha$-subunit, GPA 1 , was identified previously (Tolkacheva et al . 1994). By anal ogy with the roles in mating of the GPA 1 and Gpal G $\alpha$ subunits in budding and fission yeasts, it was hypothesized that the $C$. neoformans GPA 1 protein might be coupled to a pheromone receptor and therefore al so have a role in mating. However, by sequence homology comparisons, we find that GPA 1 shares greater identity with a distinct class of $\mathrm{G} \alpha$ proteins involved in sensing nutrient deprivation during pseudohyphal growth in Saccharomyces cerevisiae (GPA2) (Lorenz and Heitman 1997) and mating in Schizosaccharomyces pombe (G pa2) ( $N$ akafuku et al. 1988; Isshiki et al. 1992; Regenfelder et al. 1996). Because several of the establ ished pathogenic factors in C. neoformans are induced by nutrient starvation, we hypothesized that GPAl might regulate nutrient signaling and virulence in this organism.

To test this hypothesis, we disrupted the $C$. neoformans gene encoding the $\mathrm{G}$-protein $\alpha$ subunit homolog GPA 1. In contrast to the isogenic GPA 1 wild-type strain, the gpal mutant strain exhibited a severe mating defect. Importantly, the gpal mutant strain al so failed to induce two well-established virulence factors, capsule and melanin, in response to environmental signals. Correspondingly, the gpal mutant strain was significantly less pathogenic than the isogenic GPA 1 wild-type strain in a rabbit model of cryptococcal meningitis. Reintroduction of the wild-type GPA 1 gene complemented the gpal mutant phenotypes, restoring mating, capsule formation, melanin production, and virulence. In addition, exogenous CAMP also suppressed the gpal mutant phenotypes. Our findings reveal that GPA 1 is required for regulation of mating and virulence in response to diverse environmental stimuli and suggest that GPA 1 may regulate these events via adenylate cyclase. Our studies and related work in diverse yeast and fungi ( $U$. maydis, S. cerevisiae, C. parasitica, S. pombe) suggest a conserved role for G-protein-mediated CAMP production in signaling cascades regulating differentiation and virulence (Isshiki et al. 1992; Gao and Nuss 1996; Regenfelder et al. 1996).

\section{Results}

Disruption of the $C$. neoformans GPA1 gene

To el uci date cellular functions of the GPA $1 \mathrm{G} \alpha$ subunit homolog in C. neoformans, we introduced mutations in the GPA 1 gene. For this purpose, a sel ectable marker was inserted into the middle of the gene, yielding a gpa1::ADE2 mutation for gene disruption by homologous recombination. Similar approaches have been im- plemented recently to functional ly del ete other genes in C. neoformans, including CNA1 (Odom et al. 1997), CAP59 (Chang and Kwon-Chung 1994), CAP64 (Chang et al. 1996), laccase (Salas et al. 1996), and urease (G. Cox, pers. comm.).

Fifty initial candidate gpal disruption strains were selected by the restoration of adenine prototrophy following biolistic transformation of a $\Delta$ ade2 strain (M 049) with the gpa1::ADE2 disruption al lele (Fig. 1A). Of these, two were found to have a replacement of the GPA 1 gene by the gpa1::ADE2 allele. First, Southern hybridization of genomic DNA from these two strains with a probe spanning the entire GPA1 gene revealed that the gpa1::ADE2 allele had integrated into the restriction fragment containing the endogenous GPAl locus (Fig. 1B). The pattern of Southern hybridization was consistent with one or a few tandem integrations of the gpa1::ADE2 mutant al lel eat the site of insertion (Fig. 1B; data not shown). Furthermore, PCR analysis of genomic DNA, using primers that hybridize within the GPA1coding region, confirmed that the wild-type copy of the GPA 1 gene $(1.6 \mathrm{~kb})$ had been replaced by the introduced gpa1::ADE2 allele $(4.0 \mathrm{~kb})($ Fig. $1 \mathrm{C})$. One of the two gpa1::ADE2 disruption mutants was chosen for further analysis and denoted as the gpal mutant strain.

Reintroduction of the GPA 1 gene in the gpal mutant strain

The wild-type GPA1 gene was reintroduced into the gpal mutant strain by transforming the GPA1 gene linked to a fusion gene conferring hygromycin $B$ resistance (Cox et al. 1996). Genomic DN A was isolated from five hygromycin B-resistant transformants and analyzed by PCR with primers flanking the GPA 1 locus. In one of the five transformants, both the gpa1::ADE2 mutant allele and the wild-type GPA1 gene were now present, as indicated by PCR amplification of both a $4.0-\mathrm{kb}$ (gpa1::ADE2) and a 1.6-kb (GPA1) DN A fragment (Fig. 1C) and Southern blot analysis (data not shown). This transformant was denoted as the gpal +GPAl strain.

To examine expression of the GPAl gene, Northern analysis was performed on total RNA isolated from the isogenic GPA 1 wild-type parental strain, the gpa1::ADE2 mutant, and the gpal +GPA1 reconstituted strain. In contrast to the GPA 1 wild-type strain, in which a 1.3-kb message was readi ly detectable, no message was detected in the gpal mutant strain, even when grown in nitrogenlimited medium (Fig. 1D). This observation supports the conclusion that GPA1 has been functionally deleted in the gpa1::ADE2 mutant strain. Following reintroduction of the wild-type GPA1 gene by transformation, GPA 1 expression was restored in the gpal +GPAl strain. The more abundant GPA1 message detected in the gpal +GPA 1 strain may be indicative of multiple functional copies of the GPA 1 gene introduced ectopically by the transformation procedure.

The wild-type, gpal, and gpal +GPAl strains displayed identical growth rates in both liquid culture and on solid media at 25,30 , and $37^{\circ} \mathrm{C}$. In addition, all three 
Figure 1. Disruption of the $C$. neoformans GPA1 gene. (A) The $C$. neoformans ADE2 gene was inserted into an $\mathrm{N}$ del site in exon III of the GPAl gene to yield the gpal::ADE2 disruption allele. The positions of primers 1 and 2 (see $M$ aterials and Methods) are indicated by arrows and the start (ATG) and stop (TAA TGA) codons of the GPA 1 gene depicted. (B) Genomic DN A was isolated from the GPA1 wild-type strain, two gpa1::ADE2 mutant strains, and one strain in which the transformed gpa1::ADE2 allele had integrated only ectopically, digested with HindlII, electrophoresed, and analyzed by Southern hybridization with the GPA1 gene as probe. (C) Genomic DNA from the GPA 1, gpal, and gpal + GPA 1 strains was amplified by PCR with GPA 1-specific primers (1 and 2), electrophoresed in a $1 \%$ agarose gel, and stained with ethidium bromide. The open arrowhead indicates the gpa1::ADE2 allele and the solid arrow the wild-type GPA1 gene. (D) Total RNA was isolated from the GPA 1 wild-type, the gpal mutant, the gpal mutant grown in nitrogen-deprivation media, and the gpal +GPAl reconstituted strain. RNA was electrophoresed and analyzed by Northern hybridization with the GPA 1 gene as probe. Before RNA transfer, the gel was stained with ethidium bromide to determine relative ribosomal RNA concentrations for each sample.
A

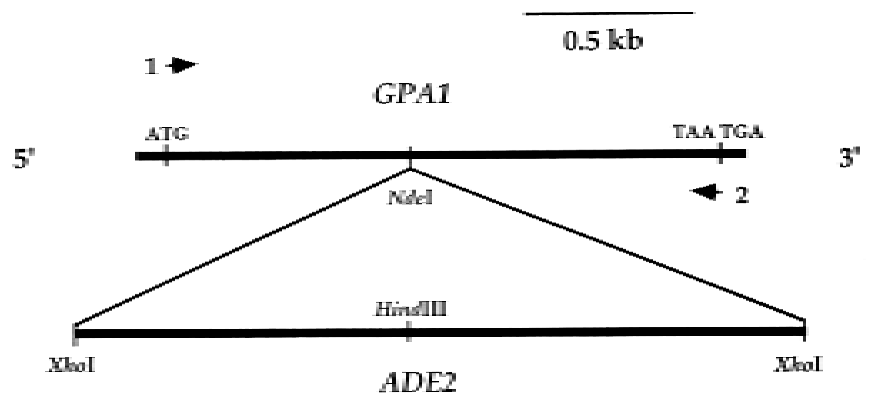

B

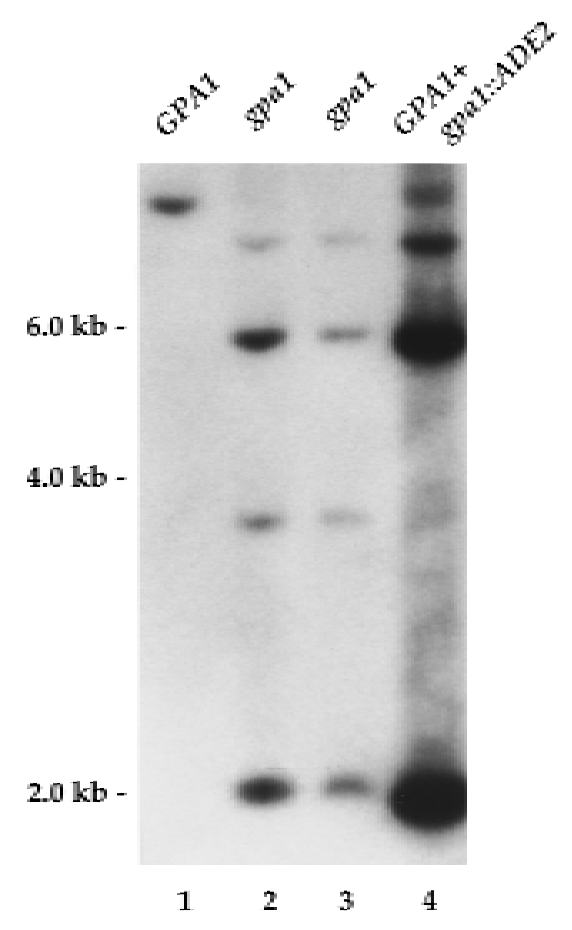

C

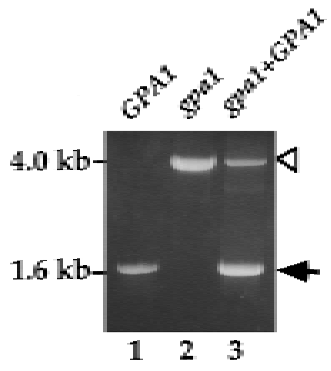

D

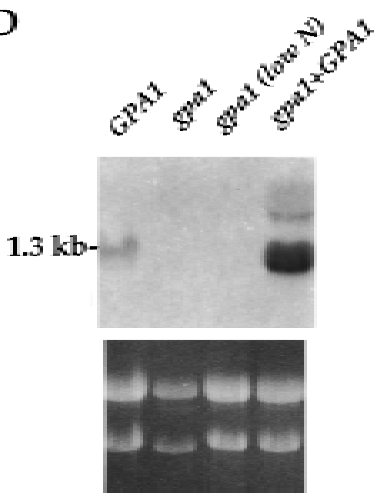

strains grew on minimal YNB media, indicating that mutation of GPA 1 does not confer any novel auxotrophies (data not shown).

\section{GPA 1 is required for mating in C. neoformans}

When cocultured on solid media limiting for nitrogen, cryptococcal cells of opposite mating type mate, undergoing a filamentous morphological change that ultimately results in nuclear fusion, meiosis, and sporulation (Kwon-Chung 1976). In contrast, when one or more of the mating partners is sterile, no filaments or spores are formed from the mating mixtures. Filament and spore formation in response to a mating partner under appropriate conditions therefore serves as an assay for mating in $C$. neoformans.

We tested whether the GPA 1 gene is requi red for mat- ing in C. neoformans. The wild-type GPA1 MAT $\alpha$, serotype A strain ( $\mathrm{H} 99)$ produced prominent hyphae and abundant basi diospores within 7 days when crossed with a serotype D strain of opposite mating type (JEC20, MATa). In contrast, only scarce and rudimentary filaments formed when the gpal mutant MAT $\alpha$ strain was crossed with the MATa mating partner JEC20 (Fig. 2). Reintroduction of the GPA 1 gene complemented this mating defect, restoring filament and basidiospore production in the gpal mutant strain to the extent observed with the wild-type GPA1 strain (Fig. 2). N ote that for these crosses a serotype $D$ mating partner was used because no serotype A, MAT a isol ate has yet been identified (Kwon-Chung and Bennett 1978).

GPA1 regulates capsule production in $\mathrm{C}$. neoformans

As a means to test whether GPA 1 is involved in sensing 


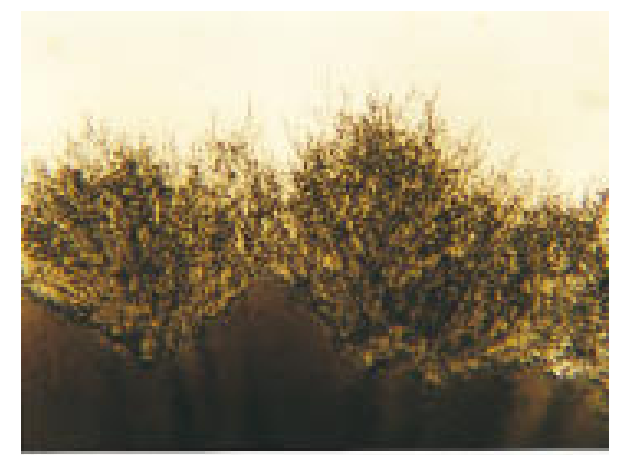

GPA1

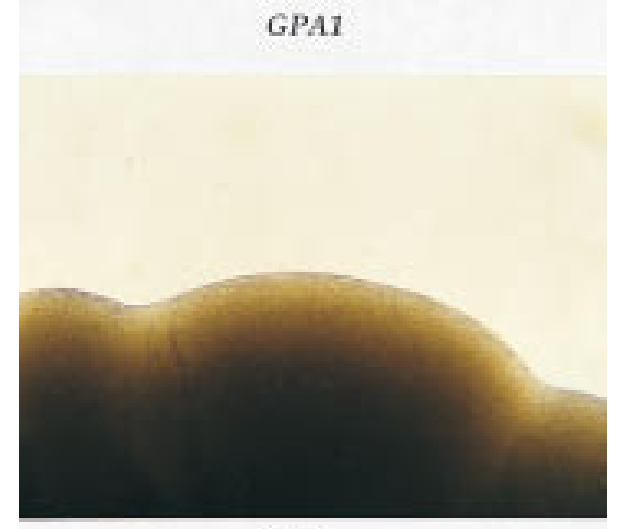

gpat

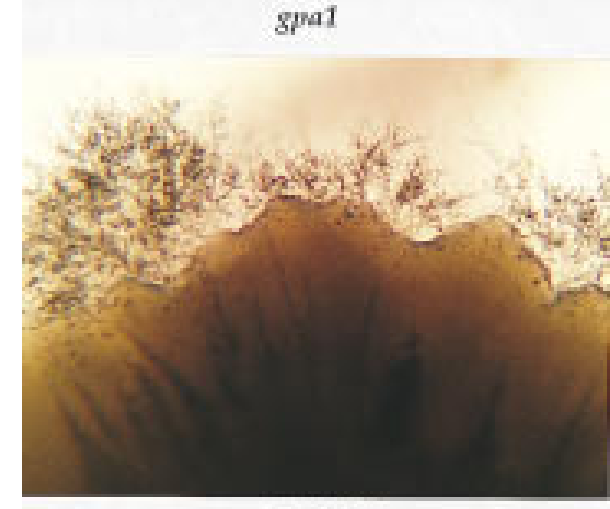

gpa1+GPA1

Figure 2. GPA 1 regulates mating in $C$. neoformans. The isogenic GPA 1 wild-type, gpal mutant, and gpa1 + GPA 1 MAT $\alpha$ strains were co-incubated with a MATa mating partner (strain JEC20) on nitrogen limiting mating media (V8 agar) for 7 days at $25^{\circ} \mathrm{C}$. The edges of the mating mixtures were photographed (50x). pheromones or more general environmental signals, we tested the effects of the gpa1::ADE2 mutation on the induction of virulence factors in response to nutrient deprivation. Visual inspection of the GPA1, gpal, and gpal +GPA1 strains on different solid media revealed that the gpal mutant strain forms very dry colonies compared with the mucoid colonies formed by the wild-type GPA1 and gpal +GPA1 strains. This difference in colony morphology is attributable to a marked decrease in capsule production by the gpal mutant, even under capsule-inducing conditions. When grown in liquid media under extreme iron limitation (low iron media +56 $\mu \mathrm{M}$ ethylenediamine-di(o-hydroxy-phenylacetic acid) [LIM +EDDHA] (Vartivarian et al. 1993), capsule production is induced in the GPA1 wild-type and gpal +GPA 1 strains and was observed readi ly when the cells are examined by a standard India ink preparation (Fig. 3). In contrast, gpal mutant cells grown under the same conditions exhibited little or no capsule when stained by the same technique (Fig. 3).

Capsule size and cell volume have been qual ified previously by measuring the packed cell volume of suspensions of $\mathrm{C}$. neoformans cells (termed the cryptocrit, by anal ogy with hematocrit) (Granger et al. 1985). The GPA1 wild-type, gpal mutant, and gpal +GPAl strains were grown in low iron media (LIM +EDDHA) for $48 \mathrm{hr}$, pell eted, and resuspended at $10^{9} \mathrm{cell} / \mathrm{s} / \mathrm{ml}$ after treatment with $10 \%$ formal in. The packed cell volume for the suspensions was 34\% for the wild-type GPA 1, 5.4\% for the gpal mutant, and $29 \%$ for the gpal +GPAl strains. Therefore, by this quantitative measurement, the capsule size was al so reduced dramatically in the gpal mutant strain compared with the GPA 1 wild-type strain or the gpal +GPAl complemented strain, confirming the macroscopic and microscopic observations on the difference in capsule size among the three strains.

\section{GPA1 regulates melanin production in C. neoformans}

C. neoformans produces melanin within the cell wall when grown in the presence of diphenolic compounds that serve as substrates for melanin production by phe noloxidase (Nurudeen and Ahearn 1979). In addition, glucose deprivation serves as an environmental signal that induces melanin production. When cultured on $\mathrm{Ni}$ -

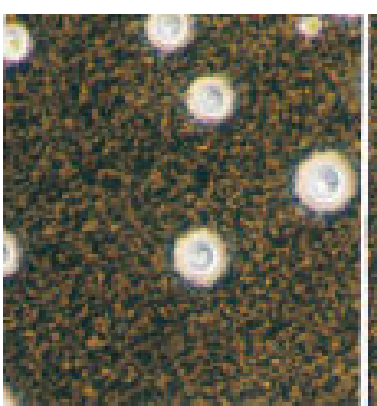

GPAI

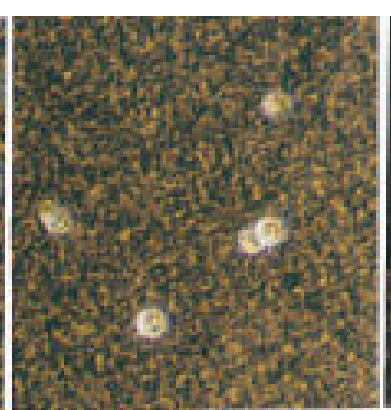

spal

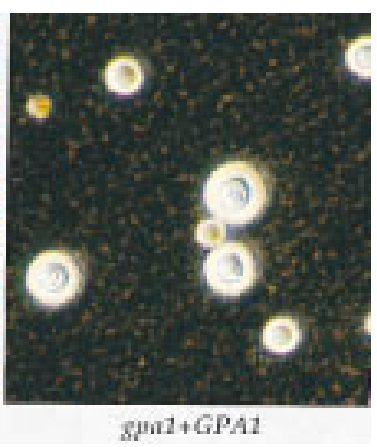

Figure 3. GPA1 regulates capsule formation in C. neoformans. The isogenic GPA 1 wild-type, gpal mutant, and gpal +GPA1 strains were cultured for $48 \mathrm{hr}$ at $30^{\circ} \mathrm{C}$ in liquid low iron media with $56 \mu \mathrm{m}$ EDDHA (an iron chelator). The polysaccharide capsule was stained by a standard India ink preparation, and the cells were photographed (200x). 
ger seed (Guizotia abyssinica) agar at $37^{\circ} \mathrm{C}$, the gpal mutant strain failed to produce melanin, in contrast with both the GPA1 wild-type and the gpal +GPA1 strains, which produced melanin and were darkly pigmented (Fig. 4A). The gpal mutant strain did produce some melanin when cultures were grown at room temperature $\left(24^{\circ} \mathrm{C}\right)$ (data not shown). Even under these conditions, however, melanin production was sporadic, occurring only after prolonged incubation, and was markedly reduced when compared with the GPA1 wild-type strain. In accord with these observations, previous studies have shown that melanin production is more pronounced at $24^{\circ} \mathrm{C}$ compared with $37^{\circ} \mathrm{C}$ (Jacobson and Emery 1991).
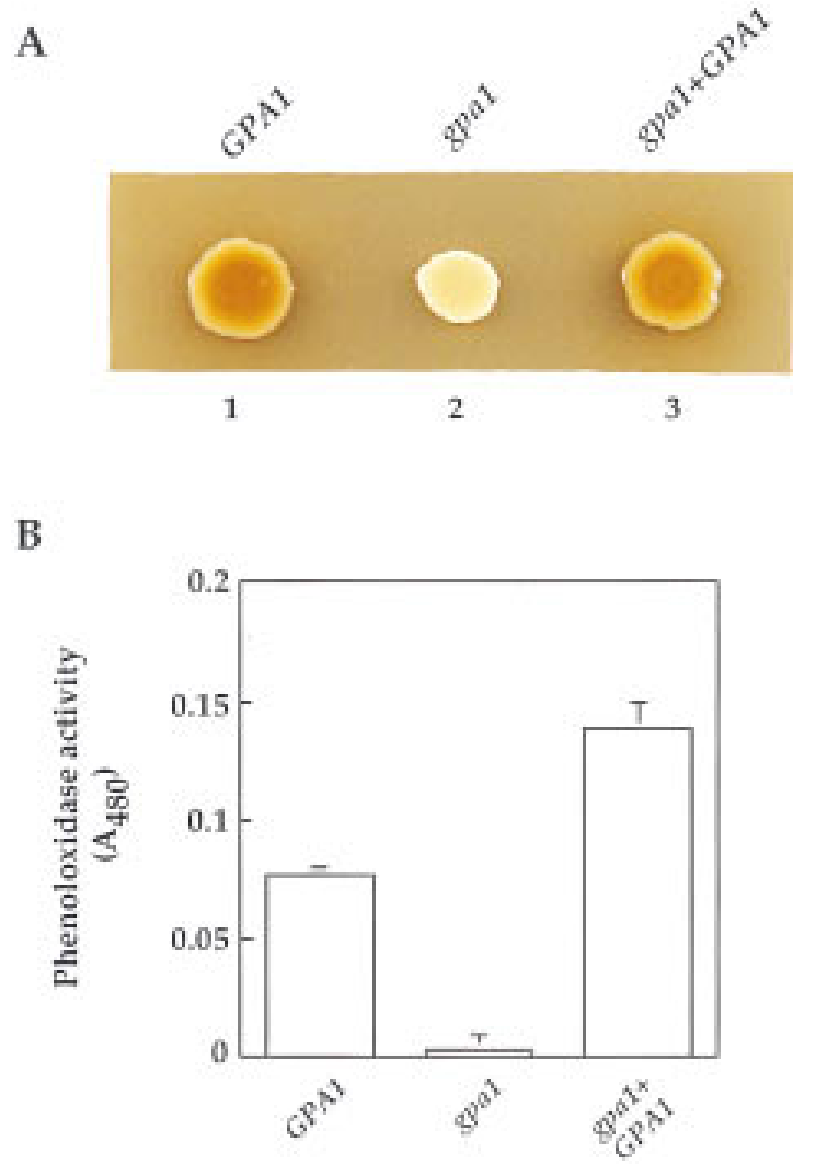

Figure 4. GPAI regulates melanin production in $C$. neoformans. (A) The GPA 1 wild-type, gpal mutant, and gpa1 +GPA 1 strains were grown on $\mathrm{N}$ iger seed agar for 7 days at $37^{\circ} \mathrm{C}$. Strains that produce melanin (GPA1, gpal +GPA1) are brown on this media, whereas strains that do not produce melanin (gpal mutant) are white. (B) The GPAl wild-type, gpal mutant, and gpal + GPA 1 strains were grown for $16 \mathrm{hr}$ at $37^{\circ} \mathrm{C}$ with glucose starvation (as described in $\mathrm{M}$ aterials and $\mathrm{M}$ ethods). Cells were permeabilized with toluene:ethanol, incubated for $2 \mathrm{hr}$ in the presence of the diphenolic substrate caffeic acid, and cellular phenol oxidase activity assayed spectrophotometrically by measuring the appearance of melanin in the supernatant by the change in absorbance at $480 \mathrm{~nm}$. Values represent the mean of three separate but identical cultures for each strain; error bars indicate standard error of the mean.
The rate-limiting step in melanin production is catalyzed by the enzyme phenoloxidase. We wished to address whether the phenoloxidase enzyme is expressed and functional in the gpal mutant cells. For this purpose, we employed a quantitative assay involving spectrophotometric measurement of melanin production by permeabilized cells exposed to diphenolic compounds (Polacheck et al. 1982; Rhodes 1986; Torres-Guererro and Edman 1994). Cultures of the GPA 1 wild-type, gpa1 mutant, and gpal +GPA1 reconstituted strains were grown in glucose-deprivation media and permeabilized with toluene:ethanol. Caffeic acid was added to the cell suspensions, and the absorbance monitored at $480 \mathrm{~nm}$. By this assay, no melanin was produced by the permeabilized gpal mutant cells, whereas significant amounts were produced by the GPAl wild-type and the gpal +GPA 1 complemented strains (Fig. 4B). These findings suggest that the gpal mutant strain fails to express active phenoloxidase enzyme under glucose starvation conditions, especially when compared with the GPA1 wild-type and gpal +GPA1 strains.

\section{GPA1 is required for growth of C. neoformans in vivo}

Cryptococcal mutants deficient in melanin or capsule production are less virulent than wild-type strains in animal models of cryptococcal infection (Fromtling et al. 1982; Kwon-Chung et al . 1982; Torres-Guererro and Edman 1994; Chang et al. 1996). Because GPA 1 is required to induce capsule and melanin production in response to environmental signals in vitro, we tested whether GPA 1 is required for virulence in vivo. To address this issue, we assessed the ability of the GPA1, gpal, and gpal +GPA1 strains to survive in the maintenance phase of a meningeal infection using a rabbit model of cryptococcal meningitis (Perfect et al. 1980). Corticosteroid-immunosuppressed rabbits were inoculated intrathecally with equivalent numbers of cells of each of the three strains, and quantitative cerebrospinal fluid (CSF) cultures were obtained over the course of a 2-week infection. By the 10th day of infection, there was a $>10,000$-fold difference between the number of gpal mutant cells remaining in the CSF of infected rabbits compared with the isogenic GPA 1 wild-type strain (Fig. 5).

Reintroduction of the wild-type GPA1 gene (gpa1 +GPA1 strain) largely, al beit not completely, complemented this gpal mutant phenotype to restore virulence (Fig. 5). The wild-type level of virulence was not compl etely recapi tulated in this reconstituted strain, which may be attributable to differences in expression between the endogenous and ectopic GPA 1 genes.

\section{Exogenous CAMP suppresses gpal mutant phenotypes}

In other microorganisms, $\mathrm{G} \alpha$ subunits with identity to the $C$. neoformans GPA 1 protein regulate CAM $P$ production via adenylate cyclase. We therefore tested whether GPA1 has an analogous role in this organism by testing 
A

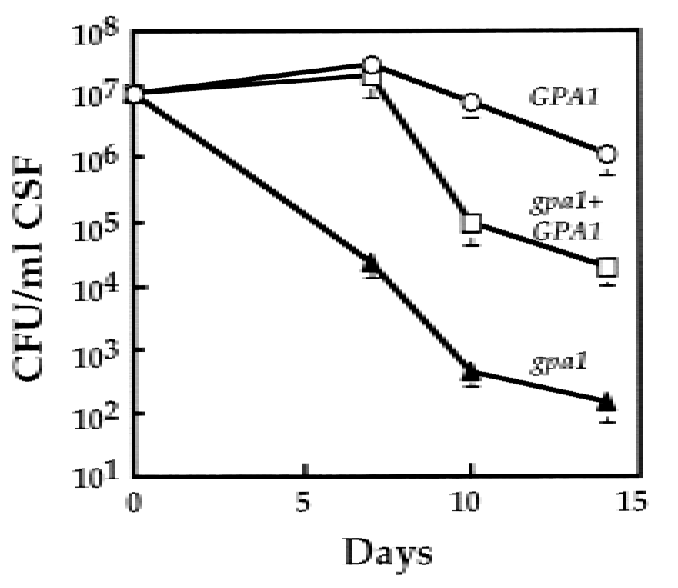

B

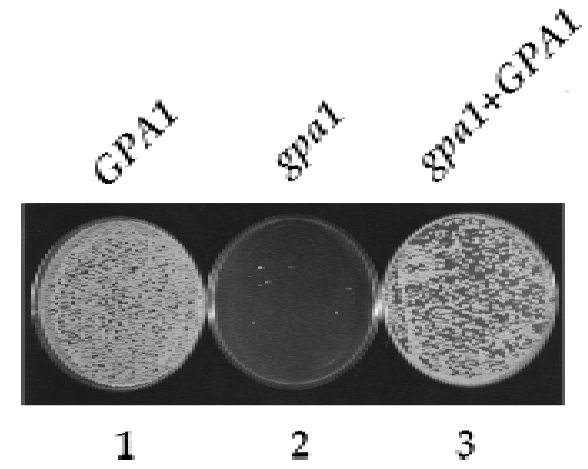

Figure 5. GPA 1 is required for virulence of $C$. neoformans in a rabbit model of cryptococcal meningitis. (A) Rabbits (four for each strain) were immunosuppressed with corticosteroids and inoculated intrathecally with $10^{8}$ cells of the isogenic GPA 1 wild-type, gpal mutant, and gpal +GPAl strains. CSF was removed on days 7,10 , and 14 following inoculation, and the number of surviving organisms was determined by serial dilution and plating on YPD medium. Each data point represents the mean of all cultures for each strain, and the standard error of the mean is indicated. (B) Equal volumes (100 $\mu \mathrm{l})$ of CSF obtained from a rabbit infected with the GPA1 wild-type, gpal mutant, and gpal +GPA 1 reconstituted strains were plated on YPD medium and incubated for $72 \mathrm{hr}$ at $30^{\circ} \mathrm{C}$. whether CAMP could suppress any or all of the gpal mutant phenotypes.

The mating defect of the gpal mutant was suppressed by exogenous CAMP. When $10 \mathrm{mM}$ CAM P was added to V8 (nitrogen-poor) mating media, mating fil aments were observed by $48 \mathrm{hr}$ around the mating mixture of gpal mutant cells and a MATa mating partner, JEC20 (data not shown). Following 7-10 days of incubation, abundant filaments and basidiospores were present (Fig. 6). CAM P did not significantly enhance mating by either the GPA 1 wild-type or gpal +GPA 1 strains, nor did it all ow any of the three strains to mate under nitrogen-rich conditions (data not shown). Additionally, CAMP did not stimulate haploid fruiting by the GPA1, gpa1, or gpal +GPA 1 strains grown on V8 media over the course of a 2 week period (data not shown).

In addition, $10 \mathrm{~mm}$ CAMP in either solid or liquid me dia restored capsule formation in the gpal mutant and further induced capsule in the GPA1 wild-type strain grown in capsule-inducing media (Fig. 7A, B). M ost striking was the vigorous production of a polysacchari de capsule by the otherwise hypocapsular gpal mutant cells in cAMP-containing, low-iron media. The gpal mutant cells, which have a slightly smaller diameter than their GPA1 wild-type counterparts when grown in the absence of exogenous CAMP, were indistinguishable from wild-type when $10 \mathrm{~mm}$ CAMP was added to the media (Fig. 7A,B). Interestingly, wild-type cryptococcal cells were stimulated to produce an even larger capsule by CAMP in iron-limiting conditions. Addition of CAMP to iron-rich media failed to induce either the GPA1 wildtype or gpal mutant strain to produce capsule, indicating that the iron-deprivation signal is still required for this induction (Fig. 7A,B).

Similarly, exogenous CAMP also suppressed a third gpal mutant phenotype and restored the ability to produce melanin. The addition of CAMP to melanin-inducing, low-glucose media stimulated production of wildtype levels of melanin in the gpal mutant strain. The GPA1 wild-type, gpal mutant, and gpa1 + GPA1 reconstituted strains produced equival ent amounts of melanin

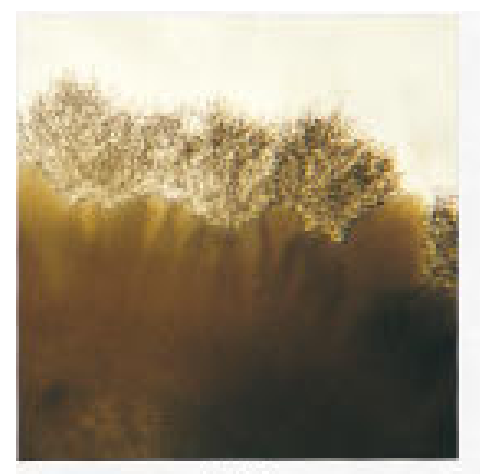

GPA1

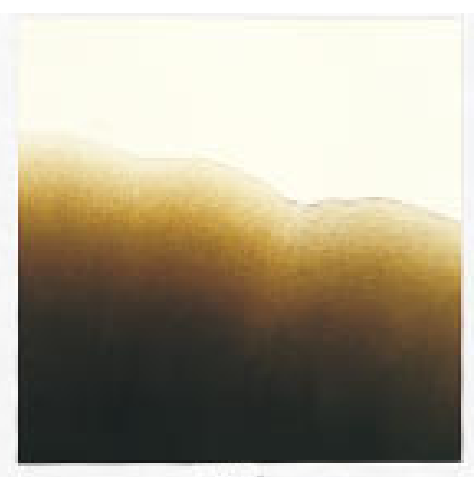

gpai

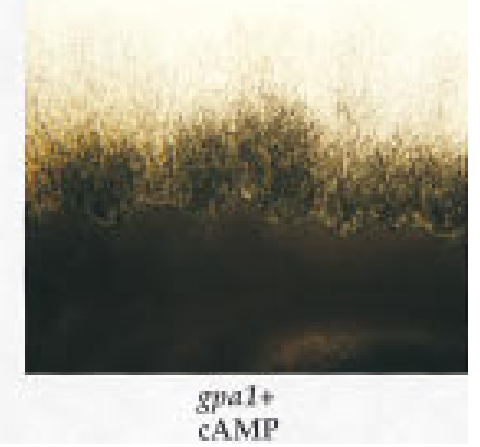

CAMP

Figure 6. Exogenous CAMP suppresses the gpal mutant mating defect. The GPA1 wild-type strain and gpal mutant strain were cocultured with a M ATa mating partner (JEC20) on V8 mating media, without (-CAMP) and with (+CAM P) 10 mM CAM P. Following 7 days incubation at $25^{\circ} \mathrm{C}$, the edges of the mating mixtures were photographed (50x). 
A

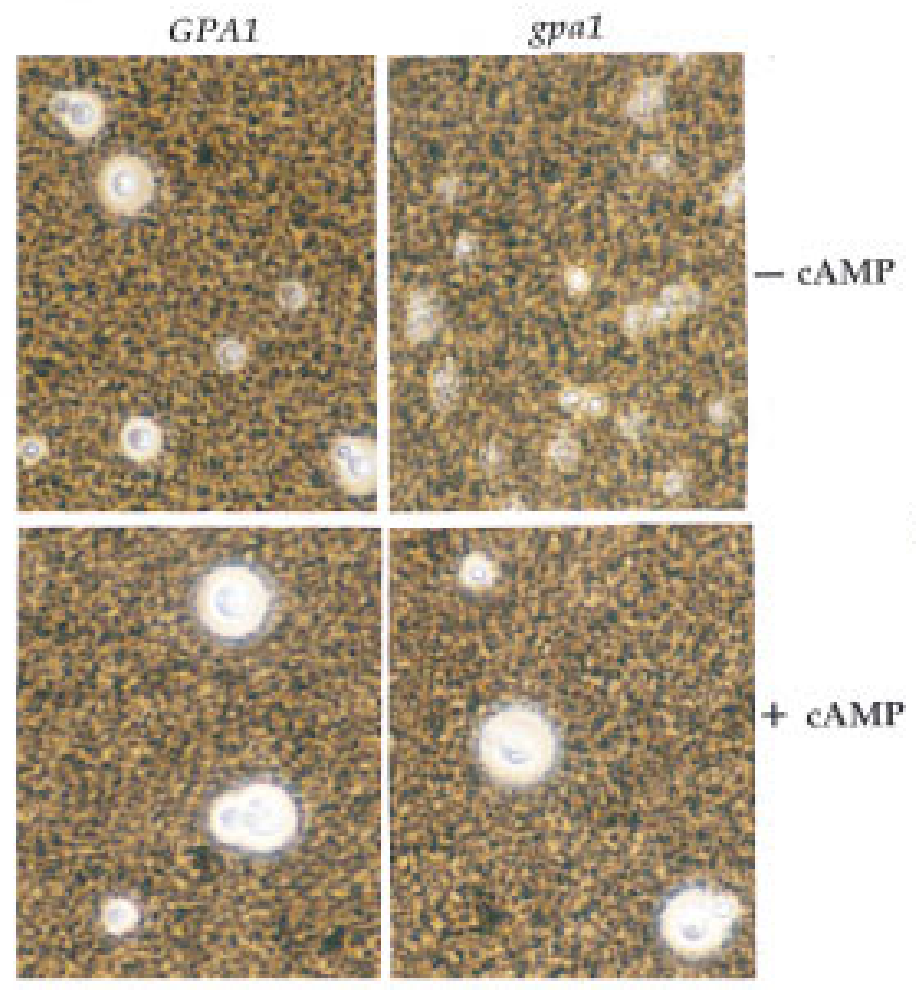

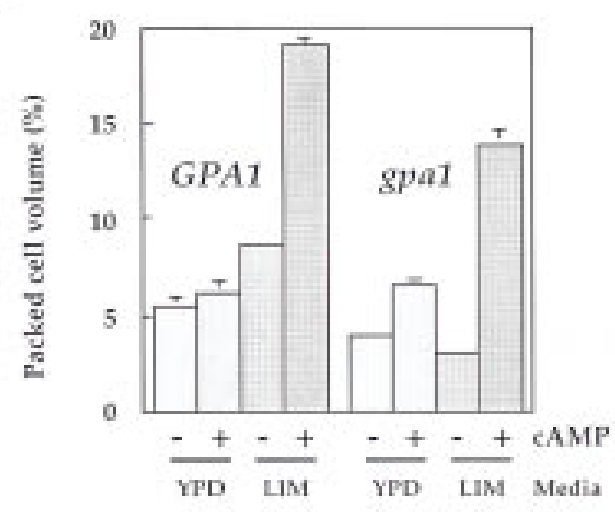

C

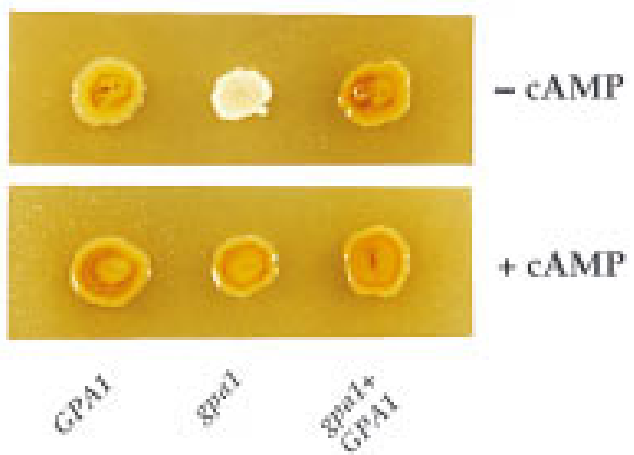

Figure 7. Exogenous CAMP restores capsule and melanin production in the gpal mutant strain. (A) The GPA1 wild-type and gpal mutant strains were cultured for $24 \mathrm{hr}$ in liquid low iron media (LIM +EDDHA), with and without $10 \mathrm{mM}$ CAMP, and cells were examined with a standard India ink preparation and photographed (200x). (B) Cultures of the GPA 1 wild-type and gpal mutant strains were suspended and normalized to $10^{8} \mathrm{cells} / \mathrm{ml}$, and packed cell volumes were measured. Results presented are the mean of duplicate measurements of two separate but identical cultures, with standard error indicated. (C) The GPA1 wild-type, gpal mutant, and gpal +GPA1 strains were cultured for 7 days at $37^{\circ} \mathrm{C}$ on $\mathrm{N}$ iger seed agar, with and without $10 \mathrm{mM}$ CAMP.

on $\mathrm{N}$ iger seed agar media containing $10 \mathrm{~mm}$ CAMP (Fig. 7C).

\section{Discussion}

Many signal transduction pathway components are remarkably conserved from organisms as diverse as yeast and fungi to man. Elucidating these remarkably conserved processes is fundamental to our understanding of basic physiological events common to all cells. Whereas components of these signaling cascades are often highly conserved, in many cases elements have been co-opted to perform different functions in different species (Blumer and Johnson 1994; Gilman 1995; Levin and Errede 1995). Therefore, for example, G proteins are highly conserved signaling components, yet function in pathways that detect an array of ligands including photons, pheromones, nutrients, and neurotransmitters (Gilman 1995). Our studies have addressed the signal transduction cascades regul ating virulence of pathogenic fungi, in part because the signaling cascades that regu- late expression of virulence factors in microorganisms are attractive targets for antimicrobial drug development.

GPA1 regulates mating and virulence in $C$. neoformans

A gene encoding a $G$ protein $\alpha$ subunit homolog was identified previously in C. neoformans and hypothesized to have a role in mating, analogous to the GPA1 and Gpal proteins of S. cerevisiae and S. pombe that functi on in detecting pheromone (T olkacheva et al. 1994). By sequence comparisons, however, we found that the $C$. neoformans GPA 1 protein shares greater identity with a different class of $\mathrm{G} \alpha$ subunits that signal nutrient starvation signals during mating and differentiation in budding and fission yeast. We took a gene disruption approach to test the hypothesis that the $C$. neoformans GPA1 protein has an analogous role in sensing nutrient deprivation signals in this important fungal pathogen.

C. neoformans gpal mutant strains were obtained by 
homologous recombination following transformation with a gpa1::ADE2 disruption allele. The resulting gpa1 mutant cells were viable, but exhibited a severe defect in mating, consistent with the hypothesis that GPA 1 has a role in mating in this organism. These findings, however, did not distinguish whether GPA 1 functions to sense pheromone or nitrogen starvation, both of which are required for mating in this organism. To address this issue, we tested whether GPA1 has a role in sensing other nutrient deprivation signals.

Our findings reveal that the GPA $1 \mathrm{G} \alpha$ subunit homolog has a critical role in regulating virulence of $C$. neoformans. Importantly, the gpal mutant cells failed to produce two well-established virulence factors, melanin and capsule, in response to environmental nutritional starvation signals. Melanin is thought to provide cellular protection from those reactive oxygen and nitrogen species produced by immune cells (Wang et al. 1995), and the polysaccharide capsule has been shown to inhibit phagocytosis (Granger et al. 1985). M utants deficient in either of these two factors have marked reductions in virulence in animal models of cryptococcosis (Fromtling et al. 1982; Kwon-Chung et al. 1982; Chang and KwonChung 1994; Torres-Guererro and Edman 1994). Correspondingly, the gpal mutant strain was avirulent in an animal model of cryptococcal meningitis. Reintroduction of the wild-type GPA 1 gene complemented the gpa1 mutant phenotypes. These observations reveal a role for GPA 1 in regulating signaling cascades required for a variety of different physiological responses beyond mating, and are consistent with the hypothesis that GPA 1 senses the nutrient deprivation signals common to these differentiation events. These observations provide evidence that GPA1 is conserved, both in sequence and in function, with the nutrient-sensing $G \alpha$ proteins of $S$. cerevisiae (GPA2) and S. pombe (G pa2).

\section{$\mathrm{G} \alpha$ subunits have conserved signaling roles in yeast and fungi}

In several yeasts and other fungi, $\mathrm{G} \alpha$ proteins have been implicated in signal transduction pathways governing mating, filamentous growth, and virulence. For example, in the basidiomycete $U$. maydis, the causative agent of corn smut, four genes encoding $\mathrm{G} \alpha$ proteins have been identified. One of these $\mathrm{G} \alpha$ subunits, $\mathrm{Gpa3}$, is required for both virulence and mating (Regenfel der et al. 1996). Similarly, in C. parasitica, an ascomycetous plant pathogen that causes chestnut blight, a G-protein-linked signal transduction pathway al so regulates virulence. A hypovi rus that infects this fungal pathogen attenuates virulence by inhibiting the $\mathrm{G} \alpha$ protein CPG-1 (Choi et al. 1995). Disruption of the CPG-1 gene results in multiple additional phenotypes, including defects in mating, asexual sporulation and, most interestingly, melanin production (Gao and N uss 1996).

In both S. cerevisiae and S. pombe, heterotrimeric G proteins are involved in the mating response by signaling the presence of pheromone (Whiteway et al. 1989; Obara et al. 1991). Both of these organisms, however, possess a second $\mathrm{G} \alpha$ protein responsible for signaling nutritional deprivation (Nakafuku et al. 1988; Isshiki et al. 1992; Lorenz and Heitman 1997). In S. pombe, as in C. neoformans, two signals are required for mating-pheromone and nitrogen starvation. M ost interestingly, in S. pombe, the $G$ pal $G \alpha$ protein signals pheromone presence, whereas a second $\mathrm{G} \alpha$ protein, $\mathrm{Gpa2}$, transduces the nitrogen starvation signal. Mutation of the S. pombe gpa2 gene impairs signaling of nutrient deprivation conditions; gpa2 null mutants mate under nitrogen-rich conditions, whereas dominant active $\mathrm{Gpa} 2$ al leles result in a partial sterile phenotype (Isshiki et al. 1992). Similarly, the $\mathrm{S}$. cerevisiae GPA2 $\mathrm{G} \alpha$ protein has an anal ogous signaling role during pseudohyphal differentiation in response to nitrogen starvation (Lorenz and Heitman 1997).

G-protein regulation of CAMP-dependent pathways in $\mathrm{C}$. neoformans and other fungi

We al so found that the gpal mutant phenotypes could be suppressed by exogenous CAMP, restoring mating, and production of both melanin and capsule in response to environmental signals. These observations provide evidence that one of the cellular functions of GPA 1 may be to regulate CAMP-dependent pathways in C. neoformans. Strikingly, similar hypotheses have emerged recently for signaling cascades regulating pseudohyphal differentiation in the yeast S. cerevisiae (Lorenz and Heitman 1997), mating in S. pombe (Isshiki et al. 1992), and mating and virulence in the plant fungal pathogens U. maydis (Gold et al. 1994) and C. parasitica (Chen et al. 1996). In these diverse organisms, highly conserved $\mathrm{G} \alpha$ subunits regul ate cAM P-dependent cell ular differentiation pathways.

In S. cerevisiae, it has been shown recently that CAMP stimulates pseudohyphal differentiation and suppresses the pseudohyphal defect of mutants lacking the GPA2 $\mathrm{G} \alpha$ subunit (Lorenz and Heitman 1997). GPA2 had been implicated previously in regulating CAMP production in yeast ( $N$ akafuku et al. 1988; Papasavvas et al. 1992). In S. pombe, gpa2 null mutants mate even in the presence of high levels of nitrogen and have CAMP levels that are reduced to one-third the level of G pa2 wild-type cells. In both S. cerevisiae and S. pombe, gpa2 mutant cells fail to increase CAM P levels in response to glucose stiml uation (N akafuku et al. 1988; Isshiki et al. 1992). These studies reveal a diverse role for $G \alpha$ proteins in the regulation of CAMP metabolism and differentiation.

CAMP has also been implicated in signaling cascades that regulate filamentous growth and virulence of plant fungal pathogens. In the dimorphic pathogenic fungus $\mathrm{U}$. maydis, del etion of the gene encoding adenylate cyclase, uacl, results in a constitutive filamentous phenotype. The addition of exogenous CAMP to uacl mutants restores a normal budding morphology (Gold et al. 1994). A nal ogous to our findings in C. neoformans, a G-protein pathway regulating virulence in the chestnut blight fungus $C$. parasitica also involves regulation of CAMP. In this case, however, the CPG1 protein serves to decrease 
CAM P levels, which results in increased virulence (Chen et al . 1996). Our findings suggest that cryptococcal GPA 1 stimulates CAMP production, resulting in increased melanin, capsule formation, and virulence. Although in some cases conserved $\mathrm{G} \alpha$ proteins acti vate, whereas others inhibit CAMP production, taken together, these findings support a conserved role for $\mathrm{G} \alpha$ subunits in regulating CAM P-dependent signaling pathways regulating mating, filamentous growth, and virulence in yeast and fungi.

\section{Implications}

Based on our findings, we propose a model outlining the mechanisms by which external signals regulate the expression of virulence factors in C. neoformans (Fig. 8). Our studies reveal that the $\mathrm{G} \alpha$ protein homolog GPA 1 has a central role in regulating mating, induction of virulence factors, and virulence in $\mathrm{C}$. neoformans. Our hypothesi s is that GPA 1 is one component of a signal transduction cascade that senses diverse environmental nutritional starvation signals and appropriately regulates cell differentiation events. The simplest hypothesis consistent with our findings is that GPA1 activates adenylate cyclase to produce CAMP, a role similar to that of related $\mathrm{G} \alpha$ subunits in other fungi and multicellular eukaryotes (Gilman 1995). An al ternative hypothesis that cannot be formally excluded is that CAMP lies in a parallel signaling cascade that, when activated, can bypass the need for GPA 1 function. Given that CAM P fully suppressed all of the gpal mutant phenotypes, and that CAMP clearly stimulates capsule production in GPA1 wild-type cells and therefore can function in signaling

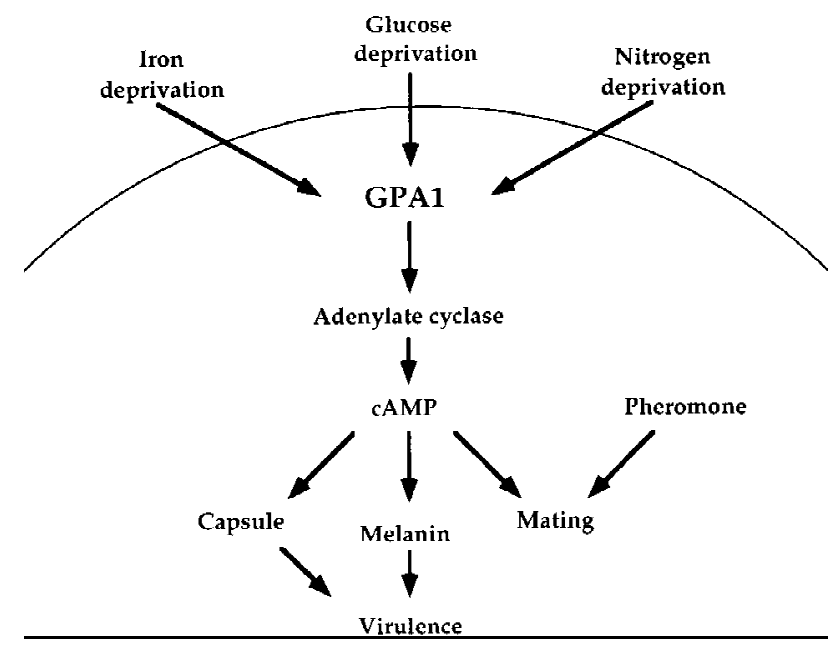

Figure 8. A model for the role of GPAl in mating and virulence in C. neoformans. Our findings support a model in which the $\mathrm{G} \alpha$ protein GPA 1 and CAMP transduce environmental signals that regulate mating and the induction of virulence factors (melanin and capsule) required for pathogenicity of $\mathrm{C}$. neoformans. Other signals (e.g., pheromone) and signaling cascades (not shown) al so likely operate in regulating differentiation and the acquisition of virulence. pathways regulating the acquisition of virulence, we favor the hypothesis that GPA 1 regulates CAM P metabolism.

Different environmental signals regulate mating, melanin production, and capsule production in C. neoformans. GPA1 serves as a signaling component common to all of these pathways, yet there is little or no cross-induction of these responses by the other environmental signals transduced via GPA 1. For example, capsule is induced in response to iron limitation but not in response to glucose or nitrogen deprivation. Similarly, mating occurs in response to nitrogen starvation but not in response to glucose or iron limitation. The only example of cross induction that we have observed involves some modest melanin production in response to nitrogen or iron limitation when diphenolic substrates are present (data not shown).

Although GPA 1 is involved in regulating mating and the expression of several virulence traits in $C$. neoformans, it is clearly not the only component of these signaling cascades, as distinct environmental signals give rise to different cellular responses. $\mathrm{N}$ otably, the specific cell surface or intracellular receptors that initiate these signaling cascades remain to be identified. At present, it is also not clear whether GPA1 is a subunit of a heterotrimeric $\mathrm{G}$ protein or acts as a solo $\alpha$-subunit, because no $G \beta$ or $G \gamma$ subunits have as yet been identified in this organism. Therefore, additional components of the signaling cascades regulating virulence remain to be identified.

In conclusion, our studies and related investigations reveal that $\mathrm{G} \alpha$ subunits fulfill multiple cellular signaling functions in diverse yeast and fungi. Moreover, these studies reveal that some signaling components are common to pathways regulating both virulence and other cellular processes, such as mating. These findings suggest that signaling pathways that originally evolved to enable organisms to respond to nutritional starvation in the environment may have been co-opted during the evolution of pathogenic organisms to serve similar regulatory functions in the often harsh environment of the infected host.

\section{Materials and methods}

Strains and media

C. neoformans strains used were derivatives of the serotype A, MAT $\alpha$ strain H99, including the ade2 mutant M 049. Mating assays with these strains were performed with the serotype D, MATa strain JEC20 (Moore and Edman 1993). Strains were grown routinely and maintained on rich medium (YPD) unless otherwise stated, and auxotrophic mutations were assessed on synthetic media and yeast nitrogen base (YNB) medium used routinely for S. cerevisiae (Sherman 1991). M ating assays were performed on V8 mating medium containing $5 \%$ V8 juice (Campbell's Soup Co.), 0.5 gram/liter of $\mathrm{KH}_{2} \mathrm{PO}_{4}$, and $4 \%$ Bactoagar (Difco) with the $\mathrm{pH}$ adjusted to 7.2 before autoclaving. Regeneration medium for biolistic transformations was as described previously (Toffaletti et al. 1993). Melanin production was assessed on N iger seed (Guizotia abyssinica) medium containing extract of 70 grams of $\mathrm{N}$ iger seed per liter ( $\mathrm{N}$ iger seed 
pulverized and boiled for $15 \mathrm{~min}$, then filtered through cheese cloth) and 4\% Bacto-agar. Capsule production was assessed in low iron medium plus $56 \mu \mathrm{m}$ ethylenediaminedi(o-hydroxyphenylacetic acid) (LIM +EDDHA) as described previously (Vartivarian et al. 1993). Synthetic low ammonia media (SLAD) contains $1.7 \mathrm{gram} /$ liter of yeast nitrogen base without amino acids and ammonium sulfate (Difco), 2\% Bacto agar, $50 \mu \mathrm{m}$ ammonium sulfate, and $2 \%$ dextrose.

\section{Disruption of the $C$. neoformans GPA1 gene}

The GPA1 gene was amplified from total genomic DNA of strain $\mathrm{H} 99$ using primers based on the publ ished sequence of the gene (Tolkacheva et al. 1994): 5'-ATGGGCGGCTGTATGTCTAC-3' (Primer 1) and 5'-TAAGATACCAGAGTCGCGTA-3' (Primer 2). The resulting 1.6-kb fragment was cloned into the pCR2.1 TA cloning vector (Invitrogen). The $\mathrm{pC}$ nade2 $\Delta$ A pa plasmid containing the ADE2 gene of $C$. neoformans (T offal etti et al. 1993) was digested with Xhol, and the ADE2-containing fragment was blunt-end ligated into the single $\mathrm{Ndel}$ site in the GPA 1 gene. The purified plasmid was precipitated onto $0.6 \mu \mathrm{g}$ gold microcarrier beads (Biorad) and biolistically transformed into the ade2 mutant strain M 049 as described previously (Perfect et al. 1993). Stable transformants were sel ected on synthetic medium lacking adenine and containing $1 \mathrm{~m}$ sorbitol .

\section{Confirmation of the gpal mutant}

PCR Genomic DNA was isolated according to the protocol by Perfect et al. (1993). Genomic DNA (50 ng) from each of 50 gpa1::ADE2 transformants was used as a template for PCR, using $50 \mathrm{pg}$ of the primers described above directed against the extreme $5^{\prime}$ and $3^{\prime}$ ends of the GPA 1 gene. The PCR reaction was performed using AmpliTaq DNA Polymerase with GeneAmp buffer and the GeneAmp PCR System 9600 (Roche). The reaction conditions were 35 cycles of denaturation at $94^{\circ} \mathrm{C}$ for 10 $\mathrm{sec}$, annealing at $55^{\circ} \mathrm{C}$ for $30 \mathrm{sec}$, and extension at $72^{\circ} \mathrm{C}$ for 6 min. PCR products were analyzed by agarose gel electrophoresis.

Southern hybridization Genomic DNA $(10 \mu \mathrm{g})$ from candidate gpal mutants was digested with HindlII. Electrophoresis, DN A transfer, prehybridization, hybridization, and autoradiography were performed as described (Sambrook et al. 1989). The probe was labeled using the Random Primed DN A Labeling Kit (Boehringher $M$ annheim) and ${ }^{32} \mathrm{P}-\mathrm{dCTP}$ (Amersham); the template for the probe was the 1.6-kb PCR fragment amplified from $\mathrm{H} 99$ genomic DN A using the GPA 1 gene-specific primers (Primers 1 and 2).

Reintroduction of the GPA1 gene into the gpal mutant strain H 99 genomic DN A was PCR-amplified with primers directed to the $5^{\prime}$ and $3^{\prime}$ ends of the GPA 1 gene, including the untranslated regions. 5'-GAACGTTCTAGACCACTAGCTGCTCTTTGGCTTCTC-3' and 5'-GCCTTATCTAGAAAGTATGTAAGTGATTATGATTCA-3' (Xbal sites underscored). The resulting 2.0-kb PCR product was digested with $\mathrm{Xbal}$ and inserted into the Xbal site in pTelHyg (Cox et al. 1996). DNA was biolistically transformed into the gpal mutant as described (Cox et al. 1996), and transformants were isolated on YPD with $200 \mathrm{U} / \mathrm{ml}$ Hygromycin B (Sigma). Genomic DN A isolated from five transformants was analyzed by PCR with the GPA1 gene-specific primers.
Northern hybridization

Total RNA was isolated from cell suspensions of the GPA1, gpal, and gpal + GPA 1 strains grown in liquid YPD or SLAD (as indicated in the text) using the RN easy Midi Kit (Qiagen). Electrophoresis, RNA transfer, prehybridization, hybridization, and autoradiography were performed as described (Sambrook et al. 1989). The probe was labeled using the Random Primed DNA Labeling Kit (Boehringher Mannheim) and ${ }^{32} \mathrm{P}-\mathrm{dCTP}$ (Amersham); the template for the probe was the 1.3-kb PCR fragment amplified from CDN A using the above-described primers corresponding to the $5^{\prime}$ and $3^{\prime}$ ends of the GPAl gene.

\section{Mating assays}

Strains of opposite mating type were cocultured on V8 mating medium and incubated at $25^{\circ} \mathrm{C}$ for 2 weeks. All cultures to be tested for mating were grown on YPD medium for $48 \mathrm{hr}$ at $30^{\circ} \mathrm{C}$ immediately before inoculation on mating agar. Mating mixtures were analyzed daily for filamentation using a Zeiss Stemi SV 6 dissecting microscope at $10 \times$ magnification. Photomicroscopy was performed on representative sectors of the mating mixtures with a Nikon Axiophot-2 microscope with a $20 \times$ objective and a $2.5 \times$ trinocular camera adapter.

\section{Capsule induction}

All strains assayed for capsule production were incubated on YPD medium at $30^{\circ} \mathrm{C}$ for $48 \mathrm{hr}$ before inoculation into LIM +EDDHA. Packed cell volume measurements were performed on cultures after treatment with $10 \%$ formal in and normalization to specific cell counts (see Results) using a microhemacytometer (Fisher). The normalized cell suspensions were added to heparinized M icrohematocrit Capillary Tubes (Fisher, 02-668-66) and the ends sealed with clay. Capillary tubes were spun for $10 \mathrm{~min}$ in a Microhematocrit Centrifuge, Model MB (International Equipment Co.). Packed cell volume was measured, anal ogously to a hematocrit, as the length of the packed cell phase divided by the length within the capillary tube of the total suspension.

\section{Melanin production}

All strains assayed for melanin production were initially incubated on YPD medium at $30^{\circ} \mathrm{C}$ for $48 \mathrm{hr}$. The cultures were then incubated on $\mathrm{N}$ iger seed agar for 7 days at $37^{\circ} \mathrm{C}$.

Phenoloxidase activity was assayed as described previously with minor modifications (Rhodes 1986). Cells were inoculated from fresh cultures grown on YPD agar into liquid YNB $(6.7$ grams/liter) with $0.1 \%$ dextrose and incubated at $37^{\circ} \mathrm{C}$ for $16 \mathrm{hr}$ in a shaking incubator. Cells were pelleted, washed once with liquid YN B without dextrose, and resuspended in the same medium. Cells were incubated for an additional $5 \mathrm{hr}$ at $37^{\circ} \mathrm{C}$, pelleted, washed once with water, and resuspended in $0.05 \mathrm{M}$ sodium phosphate, $\mathrm{pH} 7.0$ ( $1 \mathrm{ml}$ of sodium phosphate solution for each $100 \mathrm{mg}$ of cells, wet weight).

Toluene:ethanol (1:4, vol/vol), $100 \mu \mathrm{l}$ per $1 \mathrm{ml}$ of cell suspension, was added to permeabilize the starved cells, and the mixture was vortexed for $90 \mathrm{sec}$. The cell suspensions were incubated at $30^{\circ} \mathrm{C}$ for $2 \mathrm{hr}$ either with or without $1 \mathrm{~mm}$ caffeic acid. The suspensions were pelleted in a microcentrifuge at 14,000 rpm for $30 \mathrm{sec}$ and the supernatants analyzed in a Beckman DU 640 spectrophotometer at $480 \mathrm{~nm}$. The $A_{480}$ of samples to which caffeic acid had been added was compared with a sample in which no caffeic acid had been added as the blank. 


\section{Virulence assay}

Strains were incubated on YPD medium for $48 \mathrm{hr}$ at $37^{\circ} \mathrm{C}$ and resuspended in phosphate buffered saline (PBS), pH 7.4 (Sigma) at $3 \times 10^{8}$ cells $/ \mathrm{ml}$. Twelve New Zealand white male rabbits, which had been intramuscularly injected with $2.5 \mathrm{mg} / \mathrm{kg}$ of cortisone acetate (M erck), were intrathecally inoculated with $0.3 \mathrm{ml}$ of the cell suspensions (four rabbits per strain). Daily cortisone intramuscular injections were continued throughout the course of the experiment. CSF was obtained sterily by cisternal punctures at days 7,10 , and 14 and immediately plated at various concentrations on YPD medium and incubated at $30^{\circ} \mathrm{C}$ for $72 \mathrm{hr}$ for quantitative analysis. Rabbits were sedated with 10 mg xylazine and $100 \mathrm{mg}$ ketamine given intramuscularly before all cisternal inoculations or withdrawals (Perfect et al. 1993).

\section{Acknowledgments}

We thank Mike Lorenz for comments and discussions and David Messerly and Lora Cavallo for technical assistance. This work was supported in part by the $\mathrm{N}$ ational Institute of Allergy and Infectious Diseases Interdisciplinary Research Training Program in AIDS 2T 32A I07392-06, NIAID RO1 grant AI39115, Public Health Service grants AI-28388 and AI-94-014 from the NIAID; and as a part of the Veterans Affairs Research Center on AIDS and Human Immunodeficiency Virus Infection (J.R.P.). J.H. is an assistant investigator of the Howard Hughes M edical Institute.

The publication costs of this article were defrayed in part by payment of page charges. This article must therefore be hereby marked "advertisement" in accordance with 18 USC section 1734 solely to indicate this fact.

\section{References}

Blumer, K.J. and G.L. Johnson. 1994. Diversity in function and regulation of MAP kinase pathways. Trends Biosci. 19: 236240.

Chang, Y.C. and K.J. Kwon-Chung. 1994. Complementation of a capsule-deficient mutation of Cryptococcus neoformans restores its virulence. Mol. Cell. Biol. 14: 4912-4919.

Chang, Y.C., L.A. Penoyer, and K.J. Kwon-Chung. 1996. The second capsule gene of Cryptococcus neoformans, CA P64, is essential for virulence. Infect. Immun. 64: 1977-1983.

Chen, B., S. Gao, G.H. Choi, and D.L. N uss. 1996. Extensive alteration of fungal gene transcript accumulation and elevation of G-protein-regulated CAMP levels by a virulence-attenuating hypovirus. Proc. Natl. Acad. Sci. 93: 7996-8000.

Choi, G.H., B. Chen, and D.L. N uss. 1995. Virus-mediated or transgenic suppression of a G-protein $\alpha$ subunit and attenuation of fungal virulence. Proc. Natl. Acad. Sci. 92: 305-309.

Cox, G.M., D.L. Toffaletti, and J.R. Perfect. 1996. Dominant selection system for use in Cryptococcus neoformans. J. Med. Vet. Mycol. 34: 385-391.

Fromtling, R.A., H.K. Shadomy, and E.S. Jacobson. 1982. Decreased virulence in stable acapsular mutants of Cryptococcus neoformans. Mycopathologia 79: 23-29.

Gao, S. and D.L. N uss. 1996. Distinct roles for two G protein $\alpha$ subunits in fungal virulence, morphology, and reproduction reveal ed by targeted gene disruption. Proc. Natl. Acad. Sci. 93: 14122-14127.

Gilman, A.G. 1995. G proteins and regulation of adenylyl cyclase. Biosci. Rep. 15: 65-97.

Gold, S., G. Duncan, K. Barrett, and J. Kronstad. 1994. CAM P regulates morphogenesis in the fungal pathogen $U$ stilago maydis. Genes \& Dev. 8: 2805-2816.

Granger, D.L., J.R. Perfect, and D.T. Durack. 1985. Virulence of Cryptococcus neoformans: Regulation of capsule synthesis by carbon dioxide. J. Clin. Invest. 76: 508-516.

Isshiki, T., N. M ochizuki, T. M aeda, and M. Yamamoto. 1992. Characterization of a fission yeast gene, gpa2, that encodes a $\mathrm{G} \alpha$ subunit involved in the monitoring of nutrition. Genes \& Dev. 6: 2455-2462.

Jacobson, E.S. and H.S. Emery. 1991. Temperature regulation of the cryptococcal phenol oxidase. J. Med. Vet. Mycol. 29: 121124.

Kwon-Chung, J.J. and J.E. Bennett. 1978. Distribution of a and $\alpha$ mating types of Cryptococcus neoformans among natural and clinical isolates. Am. J. Epidemiol. 108: 337-340.

Kwon-Chung, K.J. 1976. Morphogenesis of Filobasidiella neoformans, the sexual state of Cryptococcus neoformans. Mycologia 68: 942-946.

Kwon-Chung, K.J. and J.C. Rhodes. 1986. Encapsulation and melanin formation as indicators of virulence in Cryptococcus neoformans. Infect. Immun. 51: 218-223.

Kwon-Chung, K.J., J.C. Edman, and B.L. Wickes. 1992. Genetic association of mating types and virulence in Cryptococcus neoformans. Infect. Immun. 60: 602-605.

Kwon-Chung, K.J., I. Polacheck, and T.J. Popkin. 1982. M elaninlacking mutants of Cryptococcus neoformans and their virulence for mice. J. Bacteriol. 150: 1414-1421.

Levin, D. and B. Errede. 1995. The proliferation of MAP kinase signaling pathways in yeast. Curr. Opin. Cell Biol. 7: 197202.

Lorenz, M.C. and J. Heitman. 1997. Yeast pseudohyphal growth is regulated by GPA2, a G protein $\alpha$ homolog. EMBO J. (in press).

Mekalanos, J.J. 1992. Environmental signals controlling expression of virulence determinants in bacteria. J. Bacteriol. 174: 1-6.

MitchelI, T.G. and J.R. Perfect. 1995. Cryptococcosis in the era of AIDS-100 years after the discovery of Cryptococcus neoformans. Clin. Microbiol. Rev. 8: 515-548.

M oore, T.D.E. and J.C. Edman. 1993. The $\alpha$-mating type locus of Cryptococcus neoformans contains a peptide pheromone gene. Mol. Cell. Biol. 13: 1962-1970.

N akafuku, M., T. Obara, K. Kaibuchi, I. Miyajima, A. M iyajima, H. Itoh, S. N akamura, K.-i. Arai, K. M atsumoto, and Y. Kaziro. 1988. Isolation of a second yeast Saccharomyces cerevisiae gene (GPA2) coding for guanine nucleotide-binding regulatory protein: Studies on its structure and possible functions. Proc. Natl. Acad. Sci. 85: 1374-1378.

N urudeen, T.A. and D.G. A hearn. 1979. Regulation of melanin production by Cryptococcus neoformans. J. Clin. Microbiol. 10: 724-729.

Obara, T., M. N akafuku, M. Yamamoto, and Y. Kaziro. 1991. Isolation and characterization of a gene encoding a G-protein al pha subunit from Schizosaccharomyces pombe: Involvement in mating and sporulation pathways. Proc. Natl. Acad. Sci. 88: 5877-5881.

Odom, A., S. Muir, E. Lim, D.L. Toffaletti, J. Perfect, and J. Heitman. 1997. Calcineurin is required for virulence of Cryptococcus neoformans. EMBO J. 16: 2576-2589.

Papasavvas, S., S. Arkinstall, J. Reid, and M. Payton. 1992. Yeast $\alpha$-mating factor receptor and G-protein-linked adenylyl cyclase inhibition requires RAS2 and GPA2 activities. Biochem. Biophys. Res. Comm. 184: 1378-1385.

Perfect, J.R., S.D.R. Lang, and D.T. Durack. 1980. Chronic cryptococcal meningitis: A new experimental model in rabbits. Am. J. Pathol. 101: 177-194.

Perfect, J.R., D.L. Toffaletti, and T.H. Rude. 1993. The gene 
encoding phosphoribosylaminoimidazole carboxylase (ADE2) is essential for growth of Cryptococcus neoformans in cerebrospinal fluid. Infect. Immun. 61: 4446-4451.

Polacheck, I., V.J. Hearing, and K.J. Kwon-Chung. 1982. Biochemical studies of phenoloxidase and utilization of catecholamines in Cryptococcus neoformans. J. Bacteriol. 150: 1212-1220.

Regenfelder, E., T. Spellig, A. Hartmann, S. Lauenstein, M. Bölker, and R. Kahmann. 1996. G proteins in U stilago maydis: Transmission of multiple signals? EMBO J. 16: 19341942.

Rhodes, J.C. 1986. A simplified assay for cryptococcal phenoloxidase. Mycologia 78: 867-868.

Sal as, S.D., J.E. Bennett, K.J. Kwon-Chung, J.R. Perfect, and P.R. Williamson. 1996. Effect of the laccase gene, CNLAC1, on virulence of Cryptococcus neoformans. J. Exper. Med. 184: 377-386.

Sambrook, J., E.F. Fritsch, and T. Maniatis. 1989. Molecular cloning: A laboratory manual. Cold Spring Harbor Laboratory Press, Cold Spring Harbor, NY.

Sherman, F. 1991. Getting started with yeast. Methods Enzymol. 194: 3-21.

T offal etti, D.L., T.H. Rude, S.A. Johnston, D.T. Durack, and J.R. Perfect. 1993. Gene transfer in Cryptococcus neoformans by use of biolistic delivery of DN A. J. Bacteriol. 175: 1405-1411.

Tolkacheva, T., P. M cN amara, E. Piekarz, and W. Courchesne. 1994. Cloning of a Cryptococcus neoformans gene, GPA 1 , encoding a G-protein $\alpha$-subunit homolog. Infect. Immun. 62: 2849-2856.

Torres-Guererro, H. and J.C. Edman. 1994. Melanin-deficient mutants of Cryptococcus neoformans. J. Med. Vet. Mycol. 32: 303-313.

Vartivarian, S.E., E.J. Anaissie, R.E. Cowart, H.A. Sprigg, M.J. Tingler, and E.S. Jacobson. 1993. Regulation of Cryptococcal capsular polysaccharide by iron. J. Infect. Dis. 167: 186-190.

Wang, Y., P. Aisen, and A. Casadevall. 1995. Cryptococcus neoformans melanin and virulence: Mechanism of action. Infect. Immun. 63: 3131-3136.

Whiteway, M., L. Hougan, D. Dignard, D.Y. Thomas, L. Bell, G.C. Saari, F.J. Grant, P. O'Hara, and V.L. MacKay. 1989. The STE4 and STE18 genes of yeast encode potential $\beta$ and $\gamma$ subunits of the mating factor receptor-coupled $G$ protein. Cell 56: 467-477.

Wickes, B.L., M .E. Mayorga, U. Edman, and J.C. Edman. 1996. Dimorphism and haploid fruiting in Cryptococcus neoformans: Association with the $\alpha$-mating type. Proc. $N$ atl. Acad. Sci. 93: 7327-7331.

Williamson, P.R. 1994. Biochemical and molecular characterization of the diphenol oxidase of Cryptococcus neoformans: Identification as a laccase. J. Bacteriol. 176: 656-664. 


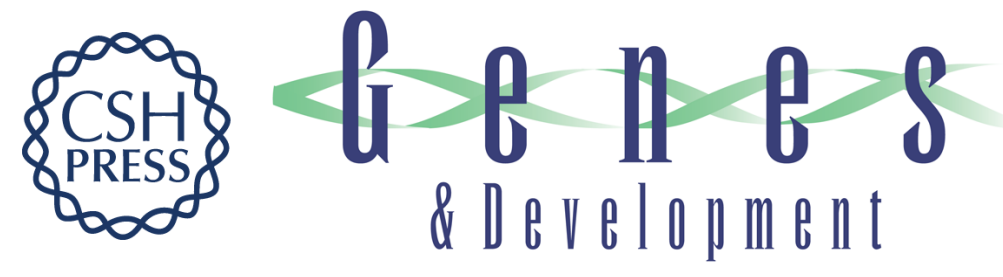

\section{Cryptococcus neoformans mating and virulence are regulated by the G-protein $\alpha$ subunit GPA1 and cAMP}

J. Andrew Alspaugh, John R. Perfect and Joseph Heitman

Genes Dev. 1997, 11:

Access the most recent version at doi:10.1101/gad.11.23.3206

References

This article cites 41 articles, 27 of which can be accessed free at:

http://genesdev.cshlp.org/content/11/23/3206.full.html\#ref-list-1

\section{License}

Email Alerting

Receive free email alerts when new articles cite this article - sign up in the box at the top Service right corner of the article or click here.

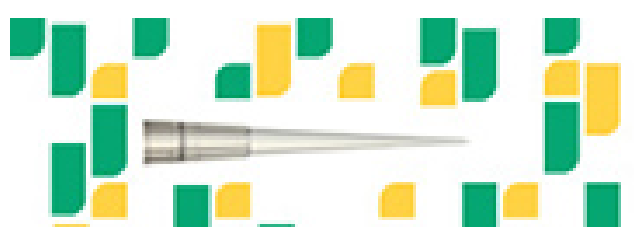

Focused on your science. 